\title{
The Holocaust in Italian Collective Memory: Il giorno della memoria, 27 January 2001
}

\author{
Robert S. C. Gordon
}

The article examines the first official, national Holocaust memorial day in Italy, the so-called Giorno della memoria (Day of memory), marked on the 56th anniversary of the liberation of Auschwitz on 27 January 2001. It looks at the ways in which the day acted as a filter for issues of national collective memory and identity, in particular state and public negotiation of the legacy of Fascism, as well as addressing broader issues of Holocaust remembrance. The article looks first at the origins of the Giorno della memoria in political and in legislative terms. Then it sketches in the events of the day itself, at national and local levels, in political, educational and cultural terms. This is followed by an analysis of media coverage and contemporary commentary, showing how various lines of interpretation addressed general issues related to the Holocaust and specifically Italian historical, ideological and contemporary questions.

\section{Introduction}

The system of racial and ideological violence known as 'the Holocaust' through vast organisational logistics and geographical reach in a moment of catastrophic dismantling of national boundaries and local autonomies. It was, in other words, to a significant degree, 'supranational' as a structure and as an experiential phenomenon. ${ }^{2}$ The emergence of the Holocaust over the postwar period (and especially from the 1960s onwards) as a recognised single 'event' in world history has only underlined this supranational aspect still further. Inevitably, however, single nations acted within and experienced the phenomenon of the Holocaust with local, national inflections; and they would later integrate it into their national histories and historiography, memory and cultural iconography in distinctly local ways, bound up with problems of national identity and collective memory, and with specific contemporary social and political issues, as much as, if not more than, with their supranational features. ${ }^{3}$

Italy is no exception to this rule. Although in bald numerical terms, when compared to many of the other combatant and/or occupied nations of Europe, the impact of the Holocaust in Italy was relatively limited, ${ }^{4}$ coming to terms with the 
Holocaust in the postwar period (or failing to do so) has meant addressing (or failing to do so) several prime problematic issues in Italian history and collective memory: these include the legacies of Fascism, histories and myths of the Resistance, relations with the Church, myths of national character and the ideological divisions of ColdWar and post-Cold-War Italian politics. In different ways and at different times, discourse around the Holocaust in Italy, whilst engaging with the complexities of its primary object, has worked as a filter for indirect engagement with these and other local, national issues.

The interplay between local and wider discourses within the representation and collective memory of the Holocaust can be seen in particularly vivid form in responses to international, major mass-media events and icons relating to the Holocaust during the long postwar period. Such phenomena would include (to name a few key examples) the camp liberation photos and newsreels of the 1940s, Anne Frank's diary, ${ }^{5}$ Adolf Eichmann's trial (1961), Willy Brandt's kneeling at the Warsaw ghetto memorial (1970), the television drama Holocaust (1978) and the films Schindler's List (1994) and Life Is Beautiful (1997). This article analyzes a recent, state-sponsored, intergovernmental addition to this list, as it played out in Italy: the first official, national Holocaust Memorial Day (or Giorno della memoria as it was called in Italy), marked on 27 January 2001, the 56th anniversary of the liberation of Auschwitz by the Soviet Red Army. The article uses the memorial day as a case study of the layering of past and present, local and general in responses to the Holocaust. In particular, it interprets the events of the day and the coverage they attracted as symptomatic of a particular phase in the memory of the Holocaust; a phase triggered by the events of 1989 and the collapse of the Cold War, as well as by the various 50th anniversaries of Second World War events through the early 1990s, during which interest in, representation and commemoration of (and, indeed, legal action concerning) the Holocaust reached a remarkable, and in some ways excessive peak. ${ }^{6}$ Both Schindler's List and Life Is Beautiful, from the list above, played a key part in this 1990s vogue, but they were the tip of an iceberg: novels, films, art, journalism, television and political discourse all made various and extensive use of the Holocaust during this period. ${ }^{7}$

At the same time, and for many of the same reasons, Italy's internal, national collective memory of Fascism and the war was undergoing radical revision also. Perhaps inevitably, the Giorno della memoria of 2001 became a crucible in which the public uses of history and memory, both national and supranational, were on vivid display.

The article looks first at the origins of the memorial day in political and in legislative terms. Then it sketches in the events of the day itself, how it was marked regionally and nationally, in political, educational and cultural terms. This is followed by an analysis of media coverage of and comment on the occasion, showing how key lines of meaning and interpretation emerged. It demonstrates the very particular status accorded to the Holocaust in the post-1989 polity in Italy, one built on an extraordinarily broad-based consensus and moral respect for the 'Event' (even across a bitterly divided political scene, which included former Fascists), but also shot through with subtle, indirect tensions and revisionist ideological positioning. Both aspects ultimately point to a period of shifting ground in the roles of the state, politics and collective memory. 


\section{Legge n. 211}

Law number 211 was passed in the Italian parliament on 20 July 2000, after debate in the Chamber of Deputies on 27 and 28 March 2000 and in the Senate on 5 April and 5 July $2000 .{ }^{8}$ Its signatories were a cross-party group of five deputies, led by the eminent writer and journalist Furio Colombo (a member of the largest governing party at that time, the ex-Communist Democratici di sinistra or DS) and including one member each of Forza Italia (FI), Alleanza nazionale (AN) and the Partito popolare italiano (PPI).

Colombo and others, including deportee associations, had been pursuing such an initiative since 1997 (Saletti 2003); but the parliamentary process of 2000 was also the culmination in Italy of an extended international, intergovernmental process, going at least as far back as the 1998 establishment in Washington of a 'Task Force for International Co-operation on Holocaust Education, Remembrance and Research'. This led in January 2000 to the turn-of-the-millennium 'Stockholm Forum on Holocaust Education, Remembrance and Research', attended by over 40 governments, whose final declaration included an undertaking to 'encourage appropriate forms of Holocaust remembrance, including an annual Day of Remembrance, in our countries'. ${ }^{9}$ Some countries had already set up a Holocaust memorial day before the Stockholm forum (e.g. Britain, although the day was also marked for the first time in Britain in 2001). ${ }^{10}$ Many did so afterwards, whether by legislation or less formal decree. ${ }^{11}$ At least two proposals for legislation in the Italian parliament other than Colombo's were in circulation in 2000, coming from both left and right, indicating both political consensus over the planned institution of a memorial day and political competition to assume its authorship. The final text, known as the 'Colombo-De Luca' law, ${ }^{12}$ read as follows:

Institution of the 'Day of Memory' in memory of the extermination and persecution of the Jewish people and of Italian political and military deportees in the Nazi camps.

\section{Article 1}

1. The Italian Republic recognizes the day of 27 January, date of the pulling down of the gates of Auschwitz, as the 'Day of Memory', to remember the Shoah (extermination of the Jewish people), the racial laws, Italy's persecution of its Jewish citizens, Italians who underwent deportation, imprisonment and death, as well as those, with differing positions and allegiances, who opposed the extermination project and, risking their own lives, saved others and protected the persecuted.

\section{Article 2}

2. On the occasion of the 'Day of Memory' (for which see art. 1) there will be organized ceremonies, initiatives, meetings and shared moments of recounting of events and of reflection, particularly in schools of all categories and levels, on what befell the Jewish people and the Italian military and political deportees in the Nazi camps, so as to preserve for the future of Italy a memory of a tragic, dark period in the history of our country and of Europe, in order that 
nothing similar might ever happen again. (Gazzetta Ufficiale, 31 July 2000, n. 177)

The law was passed nem con in the Chamber of Deputies (although there were wrangles, and a three-month delay, in the Senate). In this, parliament was responding directly to a powerful plea by Furio Colombo to remember how this very house of parliament had seen the Fascist anti-Semitic Racial Laws enthusiastically and unanimously passed on 17 November 1938.

The only signs of formal dissent in 2000 were four abstentions, three by FI members (philosopher Lucio Colletti; former minister and collaborator of Silvio Berlusconi, Cesare Previti; and former Justice Minister Filippo Mancuso) and one by the former leftist, then FI and later Centre Christian Democrat (CCD) deputy, Giulio Savelli. As this rare (near) unanimity suggests, the text was the product of careful drafting, aiming for a politically neutral pinpointing of the historical and moral necessity of Holocaust commemoration, in Italy and beyond. The compromises, omissions and elisions on display in the text are worth examining as evidence of the fault lines within Italian national and political collective memory that would emerge in various arenas in January 2001.

First, there is the delicate question of Italian responsibility. Despite the openly declared Italian involvement and responsibilities evoked in Article 1-'the racial laws, Italy's persecution of its Jewish citizens, Italians who underwent deportation, imprisonment and death'-several elements of the law work to de-Italianise the events commemorated, starting with the name of the day itself. Il giorno della memoria is decidedly neutral and universalist, in contrast, for example, to the British 'National Holocaust Memorial Day'.' The date, 27 January, is also distinctly internationalist, rooted in the by-now universal symbol of Auschwitz, with little that is specifically Italian. ${ }^{14}$ Indeed, a large number of European countries chose the same date, as if to 'Europeanise' the day. This contrasts with earlier Italian proposals, such as Colombo's suggestion of 16 October, the date of the infamous roundup and deportation of over 1,000 of Rome's Jews in $1943 .{ }^{15}$ Furthermore, twice in the law, the site of suffering of Holocaust victims is identified simply as 'the Nazi camps', with no reference to Italian collaboration or to camps on Italian territory that were integrated in different ways into the system of the Final Solution (Walston 1997). Finally, Article 2 lays clear emphasis on the memory of victimhood rather than responsibility and, again, adds a European level alongside the Italian experience, a move which neutralises responsibility ('a tragic, dark period in the history of our country and of Europe').

Secondly, there is the issue of ideological balance. Lucio Colletti and other objectors in the parliamentary debate were keen to set the memory of Holocaust victims alongside the memory of Communist victims of the 20th century; victims of 'all oppressive ideologies [...] before, during and after the 1939-1945 war', as one AN deputy phrased it (Mi ricordo 2001, p. 15). Supporters of the ColomboDe Luca law responded by presenting the 'Shoah' as representative of all ideologically motivated violence, rejecting the idea of memory as a 'zero-sum' game, whereby memory of one event takes away memory from another. Nevertheless, signs of strain over ideological balance clearly remain in the law, 
in aspects which implicitly distance the Holocaust from Fascism. At least two aspects move in this direction: first, Article 1 insists in rather a forced and oblique manner that Holocaust resisters came from both Fascist and anti-Fascist sides ('with differing positions and allegiances'). ${ }^{16}$ Further, and most importantly, the terms 'Fascism' and 'Fascist' are strikingly conspicuous by their complete absence from the text of the law (Sarfatti, quoted in De Pasquale 2001, p. 15).

Thirdly, in the somewhat repetitious phrasing, we can see reflections of the problem of setting in apt (and politically acceptable) relation the Italian, Jewish and Italian-Jewish experiences of the Holocaust (and Nazi violence generally). Three attempts are made in the short text to find a formula for precisely which victims are to be commemorated:

- 'in memory of the extermination and persecution of the Jewish people and of Italian political and military deportees in the Nazi camps';

- 'to remember the Shoah (extermination of the Jewish people), the racial laws, Italy's persecution of its Jewish citizens, Italians who underwent deportation, imprisonment and death';

- 'reflection [...] on what befell the Jewish people and the Italian military and political deportees in the Nazi camps'.

Uncertainty is evident in several respects here: the 'Jewish people' is set alongside various categories of Italians, but there are no Italian Jews at any point (only 'Jewish citizens' in the second extract, followed by an apparently distinct 'Italians'). ${ }^{17}$ And what happens to these two apparently separate categories (Jews and Italians) is blurred in the first extract and merged in the vaguest of formulae in the second ('what befell'). This is symptomatic of an ongoing problem in the conception of the Italian Giorno della memoria and in its collective memory of the war: how to encompass and order in the general collective memory three distinct categories of victims - the approximately 8,000 Jewish deportees from Italy; the approximately 30,000 Italian political (i.e. mostly Resistance-related) deportees; and the approximately 600,000 Italian military internees (i.e. army soldiers interned after the Armistice of 1943). ${ }^{18}$ Thus, the apparently numerically minor Italian involvement with the Holocaust of Europe's Jews impacts upon the numerically larger and symbolically massive issues of the Resistance and the fate of the army and the nation in 1943. As we will see below, this ambivalent overlapping constitutes one of the core sources of significance of the day as a whole.

Finally, a number of aspects of the text of the law raise issues regarding the pedagogical and moral purpose of the memorial day and the nature of collective memory. Article 2 makes clear the primarily pedagogical nature of the day itself, with its emphasis on events in schools. ${ }^{19}$ The sense of moral instruction is extended by the emphasis in Article 1 on the counterbalance to the darkness and evil of the Holocaust in exemplary figures, who risked their lives to save others. This imposition of memory from above, the intervention of the state as pedagogue and moral instructor, is itself not without its difficulties, of course, as commentators would point out in 2001. The law's description of the rituals and events to be enacted on the day are, however, notably non-prescriptive, informal and 'from below': 'ceremonies, initiatives, meetings and shared moments of recounting of events and of reflection'. 
This list seems to encourage particularly open and organic forms of collective memory.

\section{January 2001: Events}

27 January fell on a Saturday in 2001 (as it had in 1945). ${ }^{20}$ Events of various kindsexhibitions, readings, concerts, discussions, testimonies, processions, religious ceremonies and film projections - were scheduled across Italy, in most cities and many smaller towns. Many of these were public, official or semi-official and, as prompted by the legislation, often aimed at schoolchildren. Scheduling commonly spread to include the Friday and the Sunday, in part because of the weekend and in part out of respect for the Jewish Sabbath. The largest national initiative on the day itself was a public procession, co-organised by the trade unions, held in Milan ('città medaglia d'oro della Resistenza' as La Repubblica tellingly describes it; Luzi 2001). Leading from the Piazzale Loreto (site of the public display of Mussolini's body in 1945) to the city's central public space, the Piazza Duomo, the procession was attended by a respectable crowd of 10-20,000 people, studded with dozens of simple black placards, each inscribed with the name of a concentration camp. In the Piazza Duomo, the crowd was addressed by ex-deportees (Nedo Fiano, Onorina Brambilla Pesce and the president of the deportees' association ANED, Gianfranco Maris), the Chief Rabbi of Milan, Giuseppe Laras, the Jewish community leader Amos Luzzatto, and the charismatic union leader Sergio Cofferati. A separate gathering for students was addressed by Dario Fo and the Jewish singer and performer Moni Ovadia, among others (one of over a hundred gatherings run by the Sinistra giovanile nationwide). There was also an ongoing exhibition at the nearby Palazzo Reale (Mezan 2001). In Piedmont, film projections and meetings with survivors were organised across the region. ${ }^{21}$ In Turin, a concert was held at the Teatro Regio, with a musical performance called 'I canti del ghetto' and readings of testimonies gathered by Turinese oral historians (taken from Bravo \& Jalla 1986). In Rome, the President of the Republic wrote a letter which was read out by Amos Luzzatto at a Friday ceremony at the Liceo Immanuel Kant, with ministers and leaders of the centre-left government in attendance (Tullio De Mauro, Francesco Rutelli and Luciano Violante). Plaques were unveiled to commemorate Roma or Gypsy victims and child victims in two separate ceremonies. A meeting was held in the recently opened Museum of the Liberation in the Via Tasso, the infamous location of the Gestapo headquarters in Rome, where the Minister of Culture, Giovanna Melandri, opened an exhibition on Jews in Rome, 1938-44, sponsored by Steven Spielberg's Shoah Foundation. Dutiful comments by all other major political leaders (including Fini, Prodi and Berlusconi) $)^{22}$ were reported, even where their presence at specific events was not recorded: indeed, one characteristic of the day seems to have been the relatively secondary public role played by major party and political leaders.

The concentration camp grounds at Fossoli in Emilia Romagna were opened to the public, with guides, on the Sunday. Other listings or passing mentions refer to events in Naples, Agrigento, Trieste, Florence, Bari, Bologna and elsewhere. All sporting events over the weekend were preceded by a minute's silence. 
Radio and television news broadcasts reported on the Giorno della memoria on both 26 and 27 January. Raitre scheduled a series of programmes related to the day, including documentaries, and discussion programmes appeared on Raitre, Raidue and Canale 5. The Radiotre afternoon cultural radio programme 'Fahrenheit' devoted a day to the theme of memory and the Holocaust, with guests including Piero Terracina and Lia Levi. ${ }^{23}$ Finally, several publishers launched initiatives: Mursia put on its website the list of Jewish deportees from Italy and Italian-occupied territory (from Picciotto Fargion 1991); Mondadori released a book on antiSemitism (L. Levi 2001; Fertilio 2001).

As with the passage of the legislation, the events of the day were largely pacific and respectful, and only marred by relatively petty controversies. A sample of the latter gives a sense of their scale. In a building housing the office of a DS deputy, near Padua, a door was set on fire; the unfinished scrawl '*7 January' led to the assumption that the arson attack was related to the Giorno della memoria. ${ }^{24}$ At the meeting in the Via Tasso, in Rome, the arrival of the controversial AN politician Maurizio Gasparri caused a flurry of protests from the audience ('have the decency [pudore] to leave this place', was one reported cry; Longo 2001a), before an embarrassed Gasparri was allowed to stay. A momentary political spat occurred in Milan, when it was noticed that the banner of the Lombardy Region was missing from the procession: the regional leader, FI politician Roberto Formigoni, immediately expressed regret for what he insisted was a mere administrative oversight (Cremonesi 2001). Finally, the ever-controversial and contrarian journalist (and former repubblichino) Indro Montanelli declared his objection to compulsory festivals and commemorations: 'I don't believe in days of obligation [festecomandate]. Memory should be spontaneous' (Buzzanca 2001). ${ }^{25}$

\section{Coverage and Comment}

Press and other media coverage of the Giorno della memoria was respectful and reasonably substantial without suggesting the scale of a major national event. None of Corriere, La Repubblica and La Stampa led with the story at any point, but each of them devoted full-page or half-page spreads to it more than once over the course of the 27 January weekend. If the event did appear on the front page, it was typically in comment pieces, followed up as often on the culture pages as on the news pages. ${ }^{26}$ The weekly L'Espresso bundled in with its 1 February issue a video of Holocaust testimonies, Ruggiero Gabbai's Memoria, but its most extensive written coverage occupied five pages (pp. 86-91) in the 'Cultura' section of the 25 January issue.

Coverage reflected the nature and scale of active public participation in the day, which was large in toto but capillary, made up of a great number of local initiatives with relatively small audiences (with the exception of the Milan procession). This contrasts with the large national gatherings in the hundreds of thousands seen for 25 April memorials to the Resistance and the Liberation, for example, or for larger recent political protest marches, often focused on a single city. ${ }^{27}$

A mix of reportage of events, syntheses of comments from political leaders and cultural authorities, archive images and photojournalism, ${ }^{28}$ and comment pieces went to make up the press coverage. From an analysis of this material, we can pick 
up on and develop the discussion begun in the previous section, of the historical, cultural and political tensions underlying the event.

Certain aspects of the day's events and coverage echoed 'supranational' issues and debates surrounding the Holocaust in this period. Four examples can be quickly highlighted: first, the highly charged question of the 'uniqueness' or otherwise of the genocide of Europe's Jews is picked up in Galli della Loggia (2001), in Corriere della Sera, which talks of 'twentieth-century death', taking in the Holocaust and genocides of Armenians, Russian kulaks, Cambodians and others. ${ }^{29}$ In a related vein of discussion of the nature of memory and memorial, several articles (Rusconi 2001; Segre 2001; Teofilo 2001) discuss the different ways Jews and non-Jews might treat a day such as this. The tensions between respect for the overwhelmingly Jewish identity of the victims of the Final Solution and the impulse to treat it as a universal symbol of 'man's violence to man' have been a constant in reflections on the Holocaust. ${ }^{30}$ Thirdly, the emphasis both in law 211 and in the day's events on non-Jewish Italian rescuers and resisters (such as Perlasca and Palatucci) picks up on the long-term international project run by Israel's Holocaust remembrance institution, Yad Vashem, of identifying the 'Righteous Among the Nations', and indeed on the trend set by Steven Spielberg's Schindler's List. ${ }^{31}$ Finally, there is an interesting general trend towards the recovery and recording of individual testimony, at times spoken or written, but most commonly now in the form of filmed interviews and documentaries (such as the one offered by L'Espresso). ${ }^{32}$ Again, the trend was directly influenced and funded by Spielberg, through the extensive international work of interviewing survivors of his 'Survivors of the Shoah Visual History Foundation', set up in $1994 .{ }^{33}$ As seen above, many of the local initiatives consisted of the screening of such films, typically followed by comment and open discussion.

These supranational issues emerge alongside and interact with the more locally inflected lines of response that are the prime focus of the analysis here. We can examine five issues of particular interest for the longer history of Italy's collective memory of the Holocaust and the 20th century, and for the particular conjunction of forces in play in 2001 .

\section{Un delitto italiano?}

A prime, unresolved historical issue to emerge from the 'day of memory' is that of the nature and extent of Italy's shared responsibility for the Holocaust. This applies narrowly to the local experiences of Italy's Jews (and other deportees) in the years leading up to 1943 (especially following the Racial Laws of 1938) and in the years of German 'occupation' and of the Salò Republic (1943-45). It applies more generally to Italy's role as Axis ally of Nazi Germany and therefore, in some formal sense at least, as co-perpetrator of the Final Solution alongside Germany. In other words, it has direct links to the larger question (for Italy, at least) of the moral and political legacy of collective guilt left by Fascism.

Furio Colombo's interventions before, during and after the parliamentary debates on law 211 all lay particular emphasis on Italian agency or guilt in the Holocaust. In his article for La Repubblica on 27 January 2001, he accumulates a number of individual and institutional instances of active collaboration, bureaucratic 
facilitation (as provided by the Racial Laws, for example) and passive failure to intervene. His conclusion is lapidary, using a phrase which has come to symbolise the deep fractures and illicit power at work beneath the surface of much of Italy's modern history:

the Shoah is an Italian crime [un delitto italiano], carried out in the heart of our culture, accompanied by the silence of the ruling class, of artists and intellectuals known throughout the world, who had nothing to say, no sign of protest or dissent. (emphasis added) ${ }^{34}$

Several others comment in a similar vein, drawing out different aspects of Italian co-responsibility, whether by commission or omission. Corriere della Sera's coverage on 27 January notes Luciano Violante's clinching summary grounds for accusation: that the deportation and execution of Italy's Jews could have been avoided. ${ }^{35}$ It includes an article on the drastic impoverishment of Italian science and the humanities following the removal of all Jewish professors in 1938 (see Maiocchi 1999; Ventura 1996), noting the swift execution of the order and the relief of those who acquired chairs as a result (Finzi 2001). Michele Sarfatti (2001a) notes with approval the coincidence of Italian and German Holocaust memorial dates:

This shared Italo-German date is in itself a first act of memory: although the Third Reich was undeniably solely responsible for creating Auschwitz, it is nevertheless true that Fascist Italy, both before 1943 and under Salò, chose to remain its ally, after it had learned of the extermination underway. ${ }^{36}$

The most resonant expression of Italian co-responsibility of all, however, came from the President of the Republic, Carlo Azeglio Ciampi, in his message to Rabbi Toaff on 26 January. Ciampi, self-consciously speaking as the embodiment of nation and state, took the issue of Italy co-responsibility to the very heart of Italian national identity and specifically Italian history:

The racial laws of 1938 marked the most serious betrayal of the Risorgimento and of the very idea of the Italian nation, to whose success the Jews had contributed in crucial ways. (emphasis added; quoted in Capponi 2001) ${ }^{37}$

This is a particularly bold and pointed formulation. The notion of betrayal of the ideals of the nation, located at a particular symbolic date, inevitably recalls a crucial and highly charged debate in the historiography and interpretation of Fascism, ignited (or reignited) in 1996 by Ernesto Galli della Loggia's book La morte della patria. Galli della Loggia, developing a position similar to that of Renzo De Felice, argued that 8 September 1943, with the armistice and the defection of the Italian state and army from its alliances, marked the moral and political 'death of the nation', leaving individual soldiers and citizens with an impossible choice to make, between loyalty to an invalid state and betrayal of the nation to take up the Allied or Resistance cause. The argument was one which appalled many historians, since it seemed to legitimise the Fascist state and nation. ${ }^{38}$ The debate would continue and flare up, particularly at key anniversaries, into the 21 st century. Ciampi's statement 
on the Racial Laws seems designed to reclaim an 'anti-Fascist nation' from such an analysis, by reassigning the moment of the betrayal or death of the nation to a symbolic moment of Fascist moral defection. ${ }^{39}$

Sarfatti (2001a) also seems to echo the 'morte della patria' debate when he writes in terms of a choice open to Italians in September 1943 and the patriotic legitimisation or de-legitimisation that resulted. The choice he has in mind is not, however, that of adhering to the Salo Republic, out of some misplaced sense of patriotism, or joining the Resistance, but rather the moral choice of taking up arms for the doomed Jews of central and northern Italy, the symbolic representation of all the victims (vinti) of Nazism and Fascism.

Sarfatti's argument opens up the way for a particular privileging of those who made the choice to help Jews, especially after 1943, and including, by symbolic extension, the whole of the Resistance. All those who emphasise a degree of Italian responsibility for the Holocaust - Colombo, Violante, Sarfatti, Ciampi and othersalso give space to 'righteous' figures whom the law had already established as central to the purposes of the 'day of memory'. What is distinctive about the balance in these cases is the relatively exceptional and therefore heroic status given to these figures, which works to preclude a generalised exculpatory stereotype of Italians as decent, non-racist (and essentially non-Fascist) individuals, somehow detached from the rhetoric and institutional racism of the Fascist state: the myth of the so-called italiani brava gente. ${ }^{40}$

\section{Italians as Victims}

The use of the Holocaust in Italy (the Racial Laws, the 'choices' of 1943) to build counterarguments to the 'morte della patria' thesis offers a particularly complex illustration of the simultaneously national and supranational nature of the Holocaust, and of its merging of history, memory and symbol. Ideological aspects of the same debate will be raised further below, but here it is important to balance the discussion of how the Giorno della memoria raised Italy's co-responsibility for the Holocaust, its role as perpetrator, with an indication of how it simultaneously remembered Italy and Italians as victims. The ongoing conflicts and contradictions between these two images of the nation and national identity in collective memoryperpetrators and victims, guilty and innocent - are perhaps the most important of all the issues raised by the day, its rituals and interpretations.

As Sarfatti (2001a) points out, if the Resistance is to be included in the 27 January commemorations, it cannot be a generalised Resistance, which is celebrated on 25 April each year. Instead, 27 January remembers victims, principally Italian victims: Resistance deportees, military internees and Jewish deportees. As we saw in the discussion of law 211, the precise balance and equivalence between these categories of victims proved hard to strike, but it is clear that all were victims of Nazism and/or Fascism and/or the Holocaust. Whatever the historical and moral ambivalence of this discourse of victimhood, telling stories of Italians as victims marked a further stage in a necessary process of excavation of Nazi and Fascist violence in Italy, much of which had been suppressed in history, memory and legal procedure for decades. Two episodes, two Nazi massacres (eccidi) of Italians, 
both heavily symbolic of this excavation, emerge particularly strongly in the coverage of the 'day of memory': the massacre of over 10,000 Italian troops of the Acqui division on the Greek island of Cefalonia in late 1943, following their refusal to lay down their arms to the Germans; and the murder of over 500 civilians in the small Tuscan town of Sant'Anna di Stazzema on 12 August $1944 .^{41}$

An interview in La Repubblica with Elio Toaff, Chief Rabbi of Rome, is particularly striking in the way it draws lines of connection from the Sant'Anna massacre of Italians to the memorialisation of the Holocaust. Toaff, like others, emphasises the good that came out of the catastrophe, giving the example of the priest who went out of his way to save Toaff from certain arrest in Ancona, a story of individual virtue from within the Church to contrast with ongoing controversies over the failures of the higher Church and of Pope Pius XII in particular to respond to the Holocaust. ${ }^{42}$ More tellingly still, when asked for an image of the Shoah, Toaff offers the example of Sant'Anna:

I can say that I got an idea of what the Shoah was [...] the day of the Sant'Anna massacre. I was there with a group of partisans: yes, it was really there that I saw the true face of the Shoah. I saw that face in 508 people-men, women, children and the old-assassinated, piled up in the middle of the square and burned using wood from the church pews. [...] this wasn't only a desire to massacre, to destroy as an end in itself. It was an expression of an inconceivable hatred, of one man against another man. (La Rocca 2001)

Toaff merges his own fate as a Jew in hiding, a potential victim of the Final Solution, with that of innocent Italian victims of Nazi violence, not forgetting also a mention of the partisan Resistance. The vision of the Holocaust offered is universal, deJudaicised and deracialised, a moral offence of humanity against itself, ${ }^{43}$ and therefore one in which Italians too can justifiably see themselves as victims. In other words, his brief comments work to perform one of the most crucial and potentially ambiguous tasks of the 'day of memory': to integrate the Holocaust fully into Italian history.

\section{La memoria divisa}

The tension in history and memory between Italy role's as perpetrator and as victim is complemented and complicated by another tension subtending responses to the Giorno della memoria: the ideological tension between memory of Nazi/Fascist crimes and memory of Communist crimes.

Ideological splits in the public use of 20th-century history characterised the entire period of political uncertainty and transition after 1989. Calls were made for a more 'balanced' historical memory, suggesting a neutral historical understanding of the factors which led some to choose 'black' (Fascism and Salò) and some 'red' (Resistance, particularly Communist Resistance), and the balance of principle and violence on either side. At its best, this entailed the salvaging of complex individual stories - of repubblichini; of military internees; of partisan violence, against Fascists and against other partisans - from an artificially suppressed or simplified history. 
In its more problematic manifestations, it brought a sense of facile moral whitewashing, with Fascism and anti-Fascism/Communism read as fratricidal mirror-images of each other, with little or no moral or political difference to set

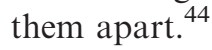

In 2001, this was intensified by the very contemporary agenda of an ongoing preelection campaign, which in May 2001 would result in the re-election of a Berlusconiled government coalition. Thus, discussion of Fascism, the war and Communism at this time meant, variously, the defence of the Italian left, the legacy of the Resistance and its founding role in the postwar democratic settlement, as the DS saw through its first parliamentary mandate in government; the legitimisation of the AN (and the Northern League, to a lesser degree) ${ }^{45}$ as a party of government; and the attempt by Berlusconi to rekindle Cold War fears of the Communist/totalitarian instincts of the left.

Lines of ideologically 'divided memory' were on display in several ways in the days surrounding the Giorno della memoria in 2001, although the alignments of left and right are by no means clear-cut, suggesting a memory which is more fractured and dispersed than neatly 'divided'. Thus, although some on the right pushed general comparisons between the Holocaust and Communist forms of totalitarian violence to make an openly political point, ${ }^{46}$ both right and left (e.g. Galli della Loggia and the editors of Diario) were receptive to a wide, comparativist perspective on modern genocide, as we saw earlier. Even commentators from the left such as Adriano Sofri, whilst objecting to facile comparisons of numbers of victims on each side of the ideological divide - what he called 'the spoils system [lottizzazione] of tragedies and deaths' - used the objection as the basis of a complex comparativist analysis, as we will see (Sofri 2001a, p. 60). ${ }^{47}$

The complexities of the parallels and contrasts drawn between Fascist and Communist violence come into clearer focus still in reflections on events in Italy, and especially on Salò and the events of 1943-45. A leading article in La Stampa on 27 January 2001 offers an interesting perspective: although not directly addressing the 'day of memory' (the article itself does not make the link and, indeed, La Stampa had no coverage in the main paper on the day itself), it picks up and comments on a recent minor cultural phenomenon of popular leftwing figures becoming interested in the difficult human stories and complex memories of Italians in the Fascist army under the Salo Republic, the so-called 'boys of Salò'. The leader-writer gives two examples: the singer and songwriter Francesco De Gregori and his song 'Il cuoco di Salò', about a poor cook hopelessly caught on the 'wrong side' of the war; and the comedian Paolo Rossi and his portrait of his father, a former repubblichino (Battista 2001). The same article links these experiences, and the moral and ideological complexities of the time, to Pier Paolo Pasolini, whose brother Guido had been killed as a Resistance fighter, but by Yugoslav Communists rather than by Nazis or Fascists: an event which, nevertheless, had pushed Pasolini towards the Communist Resistance and towards Marxism. The links on show here-to Communist internecine violence, Resistance and Fascism; to complexity in choice, consequence and memory; to the extraordinary history of Italy's northeastern border regions during the war; to Pasolini-point to a specific, symbolic site (or set of sites) of divided memory, in and around the city of Trieste. 
Adriano Sofri's article 'Le caverne dell'orrore' (2001a) uses Trieste to tackle this issue, and by extension several of the problems at stake in the 'day of memory', with typical acuity and also with symptomatic unease. Sofri's piece centres on the geographical proximity of two key symbols of Italy's history of ideologically motivated violence, and by extension the violence of Fascism/Nazism and Stalinism: the Risiera di san Sabba - a fully functioning concentration camp with crematorium on Italian soil, on the outskirts of Trieste, responsible for several thousand deathsand the foibe - the coastal caves in the Carso delta, east of Trieste, where thousands of Italians, Fascists and anti-Fascists, were killed in 1945 by Tito's partisans and other Slavs (see, respectively, Fölkel 2000; Pupo \& Spazzali 2003). He tackles the irony of their geographical proximity on several levels: first of all, noting the pedagogical function of collective memory in general and the 'day of memory' in particular, he lambasts the practice of 'joint' school trips to the area-a Nazi/Fascist atrocity in the morning, a Communist/Slav atrocity in the afternoon-and the perversion of the notion of both comparability and memory this entails. He sees the root of such facile pedagogy in the long and unnecessary repression of historical memory that has gone on in Italy (see below) and the displacements or distortions this has produced. This opens out onto a sustained discussion of how personal and collective memory makes compromises with personal past histories and loyalties. In Sofri's own case, and for many others, this means a loyalty to a Communist past, to what he sees as the still valid moral premises which led him to Communism but produced the murder of millions, epitomised in the Italian case by the foibe. Sofri's tackling of the thorny issue of the 'memory of those who have been Communists' is distinctly confessional: he reflects on the foibe as a possible inkling of what might have happened in Italy 'if we, the Communists, had won', or if the northeast (as a number of Italian Communists wanted) had seceded from Italy to join Yugoslavia. $\mathrm{He}$ is also implicitly pleading for a consideration of the moral complexity of choices on a par with pleas for the 'boys of Salò', whilst still wanting to maintain what he calls his 'alibi' of a moral distinction between Fascism and Communism. In this way, Sofri's piece is, beyond the validity of its argumentation, representative of the ways in which the trope of divided memory on display in the Giorno della memoria uncovered issues of affect and subjectivity, of personal memory as identity, as well as issues of public politics, past and present.

\section{Postwar: Silences and Symbols}

Sofri's comments on the repression of the memory of the foibe and of the Risiera di san Sabba also point to a fourth issue to emerge from the 'day of memory': Italy's coming to terms with its recent past (or failure to do so) over the postwar period. This aspect is given less prominence, as one might expect, since it is more concerned with the processes of memory themselves rather than the events of history being memorialised; but it certainly constitutes an essential complement to the core 'historical' and 'ideological' issues tackled above.

Sofri develops his discussion of memory of ideological violence in 'Le caverne dell'orrore' by moving forward into the postwar era and examining the migrations of workers into Yugoslavia, the appalling treatment many received there, especially 
after Tito broke with Moscow, and the humiliation meted out to those who returned. Michele Sarfatti (2001b) writes a piece for Diario in which he traces the omissions and distortions in the public record and the official memory in the months following the war, which amount to the very first steps in the repression of Italian responsibility for persecution of Jews and violence (part of the playing down of the need for purges of the Fascist state infrastructure). The shape of future myths and silences was already being laid down here. Several commentators point to the role of forgetting and of silence as the norm of the postwar period, the status quo against which voices of memory were forced to struggle throughout. Elena Loewenthal (2001), a columnist on Jewish culture for La Stampa, writes of the strange combination resulting today: on the one hand, long-standing 'oblivion' or 'repression', and, on the other, the massive flow of information in recent years about the Holocaust, which she calls a 'retroactive relevance [attualità retroattiva]'. The result is data without historical consciousness or understanding. Giovanni Levi (2001), reflecting on the public uses and misuses of history in Italy, Germany and Spain, asserts that Italy has not been through a period of revisionism so much as a general impoverishment and devaluation of the past itself. He blames a failure of the collective, founding myths of national unity and identity, and a failure, especially on the left, to sustain a clarity of position and values. ${ }^{48}$

Against this deficiency in collective memory and historical consciousness stand attempts to open up and understand the workings and contemporary purposes of public or collective memory. One recurrent theme is the interest in 'sites of memory', emphasised by Ciampi in his school message and by an article in Corriere which picks out a small plaque in Milan's station where the goods hoist is still the same one used in the deportations (Mezan 2001). ${ }^{49}$ Another is the (in some sense contrasting) interest in testimony, in storytelling, in individual memory rather than public memorialisation. Finally, several speakers and commentators, far from rejecting political uses of memory, work to establish links and lessons from the Holocaust to contemporary social and political issues. For example, Sergio Cofferati, in his speech to the Milan procession, talks of the dangers of xenophobia in contemporary Italy. Tullia Zevi notes lessons for present-day, multiethnic Europe, drawing parallels with the Balkan conflicts of the 1990s:

We must explain the past within the frame of our present. The Jews of then are the Bosnian Muslims of today. There is a powerful similarity; the extermination has not stopped. (Longo 2001b) ${ }^{50}$

Here the historical elaboration of the memory of the Holocaust moves from the distortions through silence and repression to a functional and symbolic use of memory for present and future, itself not without risk of ideologically loaded ambiguity and distortion.

\section{Europe}

In what we have seen so far, the supranational phenomenon of the Final Solution has been set in relation to specifically national, Italian histories and memories. 
Interacting with both these, and complicating still further the issues of history, memory and identity at stake, is one very specific 'transnational' dimension to the memorialisation of the Holocaust: the European dimension. This emerges on at least two broad levels: first, the shared, European history of the Second World War and the 'Europeanness' of the Holocaust, rooted in part at least, in European Christendom and its anti-Semitic traditions; and, secondly, the postwar project of (Western) European political, economic and cultural unification, a project enthusiastically embraced by the postwar Italian and European polity. The key idea to emerge here is a degree of underlying dependence of the latter on the former, that is, of contemporary European identity on the negative model of the European Holocaust (Probst 2001).

We saw above how the process of instituting a Holocaust memorial day was a Europe-wide one, shared by former Axis, occupied and Allied European countries alike. In Italy, one gloss on the European dimension to the memorial day reads this shared agenda as evidence of the roots of postwar European identity in anti-Fascism and anti-Nazism, in liberation and the victory of democracy. For example, Luciano Violante speaks out in support of a day dedicated specifically to the Holocaust (and not to totalitarianism and genocide more broadly) because,

the civic identity of Western Europe today was built on the struggle against Nazism and Fascism. That is why we are free. It is not that we want to forget other tragedies, but rather to mark out our own identity. (Grignetti 2001)

Violante's line is, essentially, a restatement of the early postwar 'anti-Fascist' settlement, in Italy and Europe, one which has shown distinct signs of fraying in the post-1989 era (Luzzatto 2004). Others take up a more nuanced position. Rusconi (2001) points out the remarkable consistency across Europe (for all the inevitable national particularities) in the chain of anti-Semitic events of the 1930s and 1940s, leading from indifference to outright hostility to legislative racism with next to no outcry or resistance to genocide. The purpose of memory, of 'Europeans' memory', is what he calls a necessary 'self-critical reconstruction'. 51 Michele Sarfatti (2001a) takes this a stage further, drawing a direct link between the Holocaust and the contemporary European Union:

the millions of Jews killed were one of the results of an appalling material attempt to achieve a 'European union', which, in historical terms, is the immediate precedent for the democratic European union that exists today. For this reason, that memory is indispensable for our present and our future. It is for this reason, I believe, that Prodi's first journey, after being nominated President of the European Commission, was to Auschwitz.

Finally, in a second article, Adriano Sofri (2001b) draws a more philosophising line to link the Holocaust to European identity. Drawing on the work of the Jewish thinker Franz Rosenzweig (who died in 1929), Sofri identifies the figure of the modern Jew not as an inhabitant of Europe, but as the very symbol, essence and heart of Europe: 'The Jews were not in Europe: they were Europe'. The destruction of the Jews attempted by Hitler was a suicidal attack on the core of 
European identity, an attempt to split apart an indissoluble cultural bond, and the results would have been and indeed were catastrophic for Europe as much as for European Jewry. For this trauma, Europe has become anchored in the past, obsessed with a memory it cannot process, fearful of a future repetition: 'Europe [...] is becoming a large museum, or rather, a large supermarket of memory. It seems unable to live off anything but the past, and, when it thinks of the future, it crosses its fingers' (see note 6).

\section{Conclusion}

It would be wrong to overstate the scale of the inaugural Giorno della memoria of 2001. This was no immense, mass-participation national event (unlike certain Liberation commemorations on 25 April), but rather, as we have seen, a dutifully respected and widely marked addition to the calendar of national festivals and remembrances. Unlike 25 April also, 27 January garnered a telling consensus across the political spectrum, underlining the significance of the event as symptomatic of a particular period of institutional, political and cultural transition. In the period following 1989, a period of post-ideology or what Sergio Luzzatto (2004, pp. 10-13) has called in the Italian case 'post-antifascism', in which the clarity of ideological and geopolitical differences associated with the Cold War gave way to a sort of ecumenical, liberal moral piety - against violence of any kind, for universal human rights, for ethics above politics - paying homage to the Holocaust, from wherever you stood, was de rigueur. ${ }^{52}$ It was, as Gianfranco Fini put it, 'sacrosanct'.

Inevitably, this consensus was only superficial and tensions were apparent beneath the surface. In practice, both the legislation and the day itself were characterised by delicate acts of negotiation over unresolved questions of national identity, history and collective memory. Were Italy and Italians collectively victims or perpetrators, innocent or guilty, in the enactment of the Holocaust (and, by extension, in Nazi and Fascist crime in general)? What legacies remained of the 20th century's grand ideologies, Communism and Fascism, both as global phenomena and in their very particular historical manifestations in Italy? Could they be usefully compared, at either level (the gulag versus the Lager; the foibe versus the Risiera di san Sabba)? To what extent could Italy and Italians integrate the Holocaust qua European phenomenon (and thus, perhaps, as part of a notion of European history and identity) with their own sense of national identity and history, thus contributing to something like a myth of origin for the postwar 'nation of Europe'?

The resonance of these questions in responses to 27 January was enhanced powerfully by a crucial historical coincidence: that between the implementation of the Final Solution in Italy and the months of the Salò Republic, which marked such a devastating and complicated crisis in the Italian polity and nation (even if not necessarily the 'death of the nation'). Commemoration of the former brought to the fore, obliquely and thus in revealing light, many of the most fraught problems of memory and history relating to the latter. Ongoing debates about the (fading) civic religion of the Resistance (Gundle 2000) and the (returning, revisionist) memory of Salò, about 8 September 1943 and the choices of the years 1943-45, were intensified, 
perhaps surprisingly, by 27 January 2001; and conversely, otherwise uncontroversial commemoration of the Holocaust took on a harder local edge.

Finally, as Ciampi's role in the events suggests, this had some telling implications for the role of the state and its institutions, suggesting the limitations of its role as pedagogue, as 'top-down' instigator of collective memory and memory by decree (Montanelli's festecomandate), since every act of Holocaust commemoration, in this national context, seemed weighed down with particular historical and indeed ideological connotations.

These issues have continued to play a role in 27 January commemorations following 2001, each of which has produced a comparable array of initiatives and events. ${ }^{53}$ Confirmation of these continuities can be seen in the institution on 10 February 2005 of an annual 'day of memory' for victims of the foibe, a commemoration set up in clear apposition, if not quite opposition, to the Holocaust memorial day. But the 2001 events held a very particular significance, and not only because it was the first year of officially instituted commemoration. The period of transition begun with the end of the Cold War and, in Italy, the so-called collapse of the 'first Republic', was drawing to a dramatic close in early 2001, weeks before Berlusconi's second election victory and only months before the events of 11 September 2001. After 2001, the national, European and global significance of commemorating the darkest hour of the previous century would inevitably shift onto new ground and require new lines of interpretation.

\section{Notes}

[1] On the terminology of the Holocaust, see Calimani (1999, 2001).

[2] This holds true in a functional sense: historians such as Goldhagen (1996) suggest a distinctly national (i.e. German) origin and agency for the Holocaust. And from the victims' perspective also, a supranational understanding of the Holocaust might be seen as downplaying the specifically Jewish dimension of the event, although the system of annihilation was, in a sense, a response to the supranational history and culture of European Jewry itself.

[3] The literature on postwar responses to and memories of the Holocaust is vast. The fullest singlevolume survey of national responses is Wyman \& Rosenzveig (1997), which includes Meir Michaelis's essay on Italy (pp. 514-553). For case studies of, respectively, Britain, Germany, America, Italy and France (each using different methodologies), see Kushner (1994), Marcuse (2001), Novick (1999), Rossi-Doria (1998) and Wieviorka (1992). On issues of history, memory and the commemoration of the Holocaust, influential contributions include Friedlander (1992), Hartman (1994), Hoffman (2004), LaCapra (1988) and Young (1993).

[4] For the most exact figures available of Jewish deportees from Italy (8,566 deported; 7,557 killed), see Picciotto Fargion (1991). On Fascist anti-Semitism and the Holocaust in Italy, see at least the following: Collotti (2003), Meyda (2002), Sarfatti (2000) and Zuccotti (1987). For a critical bibliography of work in this area, see Cavaglion (2004, pp. 873-880).

[5] Anne Frank's diary appeared in Dutch in 1947, in English in 1952 and in Italian in 1954. It was staged on Broadway in 1955 and released as a Hollywood film in 1959 (see Novick 1999, pp. 103-104, 117-120).

[6] On the possible excesses of this vogue for the Holocaust, see Cole (1999), Finkelstein (2000) and Novick (1999, p. 1 and passim).

[7] To limit ourselves to Italy, see for example Deaglio (1991), Maurensig (1993), Affinati's (1997) and Loy (1997), and events such as the trials of Erich Priebke in 1996-1997 or Gianfranco Fini's visit to Auschwitz in February 1999. 
[8] For an account of the passage of the law through parliament (on which I have drawn here), see De Pasquale (2001).

[9] The text of the Stockholm Declaration can be read online (Stockholm Declaration 2000).

[10] On the UK memorial day, see http://www.hmd.org.uk (retrieved 31 January 2005). For arguments for and against, see Cesarani (2001) and Karpf (2001). See also Bloxham (2002) for a critique of 'liberal' and 'victim-led' (pp. 44, 57) assumptions behind the first two memorial days in Britain. (I am grateful to a reader for Modern Italy for alerting me to this source.)

[11] For a summary of memorials and legislative arrangements, see http://wwwl.yadvashem.org/ education/ceremonies/liberation/map/map.htm (retrieved 31 January 2005).

[12] Senator Athos De Luca (Greens) had been the law's main sponsor in the Senate.

[13] The phrase 'Day of Remembrance' had appeared in the Stockholm Declaration. There was a certain variety in phraseology in the press coverage, from 'Giornata della memoria' (various newpapers) to 'Giorno del ricordo' (La Stampa) to the more specific 'Giorno della Shoah' used by La Repubblica in its highly Judaic pagehead logo on 27 and 28 January ('Giorno della Shoah' accompanied by a Star of David and a menorah). Corriere della Sera's logo, by contrast, consisted of two undulating pieces of barbed wire, representing deportation and the concentration camps in a more generalised and generic way.

[14] Although, of course, Italy's most famous survivor-writer, Primo Levi, was himself liberated from Auschwitz on 27 January 1945, by the Soviet Red Army.

[15] Compare the French commemoration date of 16 July, marking the start of the Parisian roundup of 1942, in which over 13,000 Jews were detained and deported with the active participation of the Vichy police. On this event and its memorialisation, see Wiedmer (1999), pp. 38-57.

[16] The unspoken references here are probably to Giorgio Perlasca and Giovanni Palatucci, the former a convinced Fascist, the latter a Catholic police functionary, both of whom were responsible for saving significant numbers of Jews, in Budapest and Fiume respectively. Both were named during the debate in Parliament in March 2000.

[17] The Italian law, notably, uses the Hebrew term 'Shoah', preferred by many Jewish survivors and scholars to the term 'Holocaust'; most other nations, including Britain and Israel (in its Englishlanguage publications), use the latter term, despite its problems (see note 1).

[18] The recovery and validation of the experience of the latter has been a key characteristic of the shifting ground of memories of the war since 1989 (see for example Dragoni 1996, or Marcoaldi 2004, a verse-dialogue based on memories of an internee).

[19] Once again, the same emphasis is to be found in the Stockholm Declaration and therefore in many other national memorial days, including Britain's: see notes 9 and 10 above.

[20] The following two sections are based on media coverage on and around 27 January 2001: specifically, on three national daily newspapers-Corriere della Sera, La Repubblica and La Stampa - and their city supplements for Turin (La Repubblica, La Stampa), Milan (Corriere) and Rome (La Repubblica); the weekly magazines Diario and L'Espresso; and television and radio (author viewing and listening, listings and reviews). The reliance on such media sources is not without its problems, of course, and they cannot be taken to reflect 'public opinion' in any simplistic way. Instead, it needs to be read as, precisely, a mediated and plurivalent reflection of both institutional initiatives and 'on the ground' activity, filtered through the positions of particular news organs and journalists, and through the field of intellectual journalism, contributing to the workings of collective memory. For some recent reflections on related issues, see Portelli (1999), esp. pp. 15-22, 327-357.

[21] See, for example, events in Pianezza, Nichelino, Alpignano and Pinerolo, listed in La Repubblica, 26 January 2001, Turin supplement; and in Rivoli and Beiansco, listed in La Repubblica, 27 January 2001, Turin supplement.

[22] Fini, for example, keen to avoid any lapse from his party into old habits, declared this day is sacrosanct. No political force can be seen to be untouched by it' (Grignetti 2001).

[23] See insert in listings, La Repubblica, 26 January 2001.

[24] 'Attentato a sede dell'Ulivo', La Repubblica, 28 January 2001. The Rome edition of La Repubblica of the same day reported on swastikas and other anti-Semitic graffiti in the capital.

[25] A cautionary note against 'compulsory' memory was also sounded by one of the most important historians of Jews in Italy and supporters of the day, Michele Sarfatti (2001a). 
[26] An exception was Diario, a strongly committed and independent leftist political-cultural weekly (originally born as a supplement to $L^{\prime}$ Unità), which brought out and kept on sale for a full month an elaborate supplement devoted to the Giorno della memoria, covering the Holocaust, other genocides, Italian collective memory of Fascism and of the anni di piombo, the nature of human memory and cultural memory, and more (Mi ricordo 2001, passim). It has continued to produce similar supplements for each subsequent day of memory.

[27] The penetration of radio and television broadcasts was inevitably far greater; although again, within the economy of the television schedule, the most significant coverage of the day was assigned to the culturally 'serious' channels, Raitre and Radiotre, and to short items on the news. It is thus reasonable to assume that a large proportion of Italians would have been made aware of the day, with a smaller, but not insignificant number of active participants, especially in schools and 'associationist' circles.

[28] The majority of photos in the press coverage were drawn from a familiar repertory of images of deportees, trains, barbed wire, camps, dead bodies and emaciated survivors. There were a small number of images relating to Italian anti-Semitic laws (e.g. L'Espresso, 25 January, p. 88) and to the Milan procession. (Diario was an exception, again, offering a rich, although also at times eccentric array of related imagery in its special issue, Mi ricordo.) On photographic imagery of the Holocaust, see Zelizer (1998).

[29] The issue is also raised by Rusconi (2001), and, implicitly, by Diario's inclusion of articles on Latin America, Vietnam, 1970s terrorism and American racism as well as the Final Solution. On the 'uniqueness' of the Holocaust, see Bauman (1989, pp. 83-116), Katz (1994) and Marrus (1987, pp. 18-25).

[30] On the Jewishness and/or universality of the Holocaust, see Bauman (1989).

[31] Perlasca is commonly described in the coverage as 'the Italian Schindler'; see for example Porro (2001), which announces the filming by Radio Audizioni Italiane (RAI) of a mini-series of Perlasca's story. Diario lists all 281 Italians of 17,433 'Righteous Gentiles' recognised by Yad Vashem up to that time (Mi ricordo 2001, pp. 144-145).

[32] See Giuliana Tedeschi, interviewed in the Turin pages of La Stampa, 27 January 2001. The trend is related to the rise of oral history, a link made evident by a long piece on Luigi Trastulli by oral historian Alessandro Portelli (Mi ricordo 2001, pp. 90-98). On testimony, see Felman \& Laub (1992). Alongside this closer attention to the voices of individual victims (and perpetrators), the 1990s were also, paradoxically, marked by a trend towards grand public monuments and museums dedicated to the Holocaust, such as those in Washington and Berlin (Young 1993).

[33] See http://www.usc.edu/schools/college/vhi/ (retrieved 31 January 2005).

[34] The widespread use of the phrase 'un delitto italiano' probably derives from Marco Tullio Giordana's film Pasolini: Un delitto italiano and accompanying book (Giordana 1995), on the writer's murder in 1975. A web search for the phrase throws up books and articles on Fascism, the 1950s Montesi scandal, mafia kidnappings, the deaths of Mattei and Moro, and even the death of Marco Pantani.

[35] The counterexample Violante uses is Bulgaria (quoted in Capponi 2001).

[36] For a more symbolic, universalising comparison of Italian and German roles, compare Arrigo Levi, interviewed in La Stampa, 28 January: 'We are all Germans [...] each one of us is part of that human species tarnished by the guilt of Auschwitz'.

[37] Ciampi's comments were part of his ongoing campaign to use his presidency to confront and reclaim for a purposeful national identity events of Italy's past. See Nevola (2003); and see below on Ciampi's visit to Cefalonia.

[38] See, for example, the debate that followed in the magazine Liberal, issues 15-17, June to August 1996.

[39] Any such dating game has its risks: Ciampi leaves open the question as to why 1922 or 1925 (etc.) might not have been the worst moment of betrayal of the Risorgimento and the Italian nation.

[40] For an exploration of the virtues of low-level responses to the Holocaust by Italian officials, see Steinberg (1991). On the myth of italiani brava gente, see Bidussa (1994).

[41] On Cefalonia, see Breda (2001), which describes the events, the popular book (and the film, then soon to be released) by Louis de Bernières, Captain Corelli's Mandolin, and, in an insert, Ciampi's forthcoming visit in March 2001, which he had already spoken of in terms referring to the 'morte della patria' dispute ('on that day the nation did not die, it was reborn'; Breda 2001). 
Also see Rusconi (2004). Sant'Anna di Stazzema is discussed particularly because a book appeared about it in the days leading up to 27 January: see Fusani (2001), La Rocca (2001). Locations of other eccidi are mentioned in passing as of particular importance as sites of memory; for example, the listings of events in various towns in La Repubblica, 27 January 2001, ends with Marzabotto. For a recent general study of the massacres, see Franzinelli (2003).

[42] For two contributions on this long-standing, thorny historical issue, see Cornwell (1999) and Zucotti (2000).

[43] This chimes with the humanistic vision of Primo Levi, but to hear it from a rabbi only underscores the delicate negotiations between Jewish and national memory and identity at work here.

[44] A large number of examples of historical and public divisions could be adduced as illustration here: from debate around Pavone (1991) and its characterisation of the Resistance as a civil war, to the intense displays of divided public historical memory on the 50th anniversary of Liberation in April 1995, to the strange episode in summer 1995 of Francesco Rutelli's proposal to name a Roman street after the Fascist minister of education Giuseppe Bottai.

[45] A key international context here was the entry into the Austrian governing coalition of Jörg Haider's xenophobic 'Freedom Party' in February 2000 and European Union attempts to warn Austria of possible sanctions as a result. Haider came to northern Italy several times in this period, forging links with the Lega and positing a rebirth of a regional, Mitteleuropean identity.

[46] For example, Francesco Storace, reported in Grignetti (2001).

[47] See Segre (2001) on the inadequacy of the mere counting and listing of victims.

[48] By contrast Ernst Nolte, interviewed in L'Espresso, compares contemporary Italy and its relation to its past to Germany in favourable terms (Scialoja 2001). On Nolte and Germany's Historikerstreit, see Maier (1997).

[49] On 'sites of memory', see Isnenghi (1996-98) and Winter (1995).

[50] Bloxham (2002, p. 57) discusses a comparable future-oriented use of memory in the British case.

[51] Rusconi also speaks of the complicated role played by Christianity and the Church in this European history (including recent half-hearted acts of confession and revision of attitude to the Jews).

[52] On 'Holocaust piety', see Rose (1996, see pp. 41-62 [especially pp. 41-48]).

[53] Luzzatto (2004, p. 18 and passim) calls it a 'by now established new entry' in the calendar of national commemorations and festivals, a double-edged achievement, since the promotion of 27 January has facilitated an assault on the memory of the Resistance and anti-Fascism since 2001. For material relating to subsequent Giorni della memoria, see, for example, the following websites: http:/www.repubblica.it/online/cronaca/memoria/oggi/oggi.html (on 2002) (retrieved 31 January 2005); http://www.repubblica.it/online/cronaca/memoriadue/giornata/giornata.html (on 2003) (retrieved 31 January 2005); http://www.cdec.it/memoria/27gen.htm (general) (retrieved 31 January 2005).

\section{References}

Affinati, E. (1997) Campi del sangue, Mondadori, Milan.

Battista, P. (2001) 'La storia degli uomini', La Stampa, 27 Jan.

Bauman, Z. (1989) Modernity and Holocaust, Polity, Cambridge.

Bidussa, D. (1994) Il mito del bravo italiano, Il Saggiatore, Milan.

Bloxham, D. (2002) 'Britain's Holocaust memorial days: reshaping the past in the service of the present', Immigrants and Minorities, vol. 21, no. 1-2, pp. 41-62.

Bravo, A. \& Jalla, D. (eds) (1986) La vita offesa: Storia e memoria dei Lager nazisti nei racconti di duecento sopravvissuti, Franco Angeli, Milan.

Breda, M. (2001) 'Per chi suona il mandolino di Cefalonia', Corriere della Sera, 25 Jan.

Buzzanca, S. (2001) "Né oblio né revisionismo" nel giorno della memoria', La Repubblica, 28 Jan.

Calimani, A.-V. S. (1999) 'A name for extermination (Hurban, Auschwitz, Genocide, Holocaust, Shoah)', Modern Language Review, vol. 94, no. 4, pp. 978-999.

Calimani, A.-V. S. (2001) I nomi dello sterminio, Einaudi, Turin.

Capponi, A. (2001) "Anche italiani approfittarono della Shoah", Corriere della Sera, 27 Jan.

Cavaglion, A. (ed.) (2004) 'Bibliografia italiana', in Dizionario dell'Olocausto, Einaudi, Turin. Translation of W. Laqueur (ed.) (2001) The Holocaust Encyclopedia, Yale University Press, New Haven. 
Celebrazioni e polemiche (2002) La repubblica, 27 Jan. [Online] Available at: http://www.repubblica.it/ online/cronaca/memoria/oggi/oggi.html

Ceremonies (2006) 'Yad Vashem,' [Online] Available at: http://www1.yadvashem.org/education/ ceremonies/liberation/map/map.htm

Cesarani, D. (2001) 'Myth and memory', The Guardian, 24 Jan.

Cole, T. (1999) Images of the Holocaust: The Myth of the 'Shoah Business', Duckworth, London.

Collotti, E. (2003) Il fascismo e gli ebrei: Le leggi razziali in Italia, Laterza, Bari.

Colombo, F. (2001) 'La Shoah, crimine anche italiano', La Repubblica, 27 Jan.

Cornwell, J. (1999) Hitler's Pope: The Secret History of Pius XII, Viking, New York.

Cremonesi, M. (2001) 'Il giorno della memoria, migliaia in piazza per non dimenticare', Corriere della Sera, 28 Jan.

Deaglio, E. (1991) La banalità del bene, Feltrinelli, Milan.

De Pasquale, G. (2001) 'Viaggio di una legge', in Mi ricordo, supplement to Diario, vol. 4, no. 4 (special issue dedicated to Il giorno della memoria), 27 Jan., pp. 12-18.

Dragoni, U. (1996) La scelta degli I.M.I.: Militari italiani prigionieri in Germania (1943-1945), Le Lettere, Florence.

Felman, S. \& Laub, D. (1992) Testimony, Routledge, London.

Fertilio, D. (2001) 'Lia Levi: "Così insegno ai bambini a non ripetere gli orrori dei padri"”, Corriere della Sera, 27 Jan.

Finkelstein, N. (2000) The Holocaust Industry, Verso, London.

Finzi, R. (2001) 'Quei trecento posti "rubati” negli atenei', Corriere della Sera, 27 Jan.

Fölkel, F. (2000) La risiera di san Sabba, 2nd edn, Rizzoli, Milan.

Franzinelli, M. (2003) Le stragi nascoste, Mondadori, Milan.

Friedlander, S. (ed.), (1992) Probing the Limits of Representation: Nazism and the Final Solution, Harvard University Press, Cambridge, MA.

Fusani, C. (2001) "AArrivarono i nazisti e sterminarono il paese", La Repubblica, 27 Jan.

Galli della Loggia, E. (1996) La morte della patria, Laterza, Bari.

Galli della Loggia, E. (2001) 'L'inutilità dell'orrore', Corriere della Sera, 27 Jan.

27 gennaio, giorno della memoria (2006) Centro di documentazione ebraica contemporanea, [Online] Available at: http://www.cdec.it/memoria/27gen.htm

Giordana, M. T. (1995) Pasolini: Un delitto italiano, Mondadai, Milan.

Goldhagen, D. (1996) Hitler's Willing Executioners: Ordinary Germans and the Holocaust, Little, Brown, London.

Grignetti, F. (2001) 'Giornata della memoria, uniti e divisi', La Stampa, 28 Jan.

Gundle, S. (2000) 'The "civic religion" of the resistance in postwar Italy', Modern Italy, vol. 5, no. 2, pp. 113-132.

Hartman, G. (ed.) (1994) Holocaust Remembrance: The Shapes of Memory, Blackwell, Oxford.

Hoffman, E. (2004) After Such Knowledge: Memory, History and the Legacy of the Holocaust, Secker and Warburg, London.

Holocaust Memorial Day (2006). Available at: http://www.hmd.org.uk.

Isnenghi, M. (1996-98) I luoghi della memoria, Laterza, Bari.

Karpf, A. (2001) 'Memories aren't made of this', The Guardian, 26 Jan.

Katz, S. T. (1994) The Holocaust in Historical Context, Oxford University Press, Oxford.

Kushner, T. (1994) The Holocaust and the Liberal Imagination, Blackwell, Oxford.

LaCapra, D. (1988) History and Memory after Auschwitz, Cornell University Press, Ithaca.

La giornata della memoria (2003) La repubblica, 27 Jan. [Online] Available at: http://www.repubblica.it/ online/cronaca/memoriadue/giornata/giornata.html

La Rocca, O. (2001) "Ho nel cuore il prete che mi salvò la vita"”, La Repubblica, 27 Jan.

Legge, L. (2000) Gazzetta Ufficiale Serie Generale, 177, 31 July, p. 3.

Levi, G. (2001) 'Sempre caro ci fu questo passato', Mi ricordo, pp. 82-88.

Levi, L. (2001) Che cos'è l'antisemitismo? Per favore rispondete, Mondadori, Milan.

Loewenthal, E. (2001) 'Strascico di fumo', La Stampa, 26 Jan.

Longo, A. (2001a) 'An divide i sopravvissuti', La Repubblica, 27 Jan.

Longo, A. (2001b) 'Tullia Zevi e la Shoah tra lacrime e ricordi', La Repubblica, 28 Jan.

Loy, R. (1997) La parola ebreo, Einaudi, Turin.

Luzi, G. (2001) 'L'Italia ricorda la Shoah. Ciampi: non torni l'odio', La Repubblica, 27 Jan.

Luzzatto, S. (2004) La crisi dell'antifascismo, Einaudi, Turin.

Maier, C. (1997) The Unmasterable Past: History, the Holocaust and German National Identity, Harvard University Press, Cambridge, MA.

Maiocchi, R. (1999) Scienza italiana e razzismo fascista, La Nuova Italia, Florence.

Marcoaldi, F. (2004) Benjaminowo: Padre e figlio, Bompiani, Milan. 
Marcuse, H. (2001) Legacies of Dachau: The Uses and Abuses of a Concentration Camp, 1933-2001, Cambridge University Press, Cambridge.

Marrus, M. (1987) The Holocaust in History, Penguin, Harmondsworth.

Maurensig, P. (1993) La variante di Lüneberg, Adelphi, Milan.

Meyda, G. (2002) Storia della deportazione dall'Italia 1943-1945, Bollati Boringhieri, Turin.

Mezan, M. (2001) 'Noi, testimoni della Shoah', Corriere della Sera, 25 Jan.

Mi ricordo (2001) Supplement to Diario, vol. 4, no. 4 (special issue dedicated to Il giorno della memoria), 27 Jan.

Nevola, G. (2003) 'From the "republic of parties" to a "fatherland for Italians": the Italian political system in search of a new principle of legitimation', Journal of Modern Italian Studies, vol. 8, no. 2, pp. 249-265.

Novick, P. (1999) The Holocaust and Collective Memory, Bloomsbury, London.

Pavone, C. (1991) Una guerra civile, Bollati Boringhieri, Turin.

Picciotto Fargion, L. (1991) Il libro della memoria: Gli ebrei deportati dall'Italia (1943-1945), Mursia, Milan.

Porro, M. (2001) 'I cento incredibili giorni di Giorgio Perlasca, lo Schindler italiano', Corriere della Sera, 25 Jan.

Portelli, A. (1999) L'ordine è già stato eseguito: Roma, le Fosse Ardeatine, la memoria, Donzelli, Rome.

Probst, L. (2001) 'Founding myths in Europe and the role of the Holocaust', Tales and Taboo: Controversial Narratives about the Third Reich and the Holocaust Conference, Cornell University, 13 April. [Online] Available at: http://www.deutschlandstudien.uni-bremen.de/deutschlandstudien/ publika/myths.pdf

Pupo, R. \& Spazzali, R. (2003) Foibe, Bruno Mondadori, Milan.

Rose, G. (1996) 'Beginnings of the day: Fascism and representation', in Mourning Becomes the Law: Philosophy and Representation, Cambridge University Press, Cambridge.

Rossi-Doria, A. (1998) Memoria e storia: Il caso della deportazione, Rubbettino, Catzanaro.

Rusconi, G. E. (2001) 'In occhi ambigui', La Stampa, 26 Jan.

Rusconi, G. E. (2004) Cefalonia, Einaudi, Turin.

Saletti, C. (2003) 'Memorie che emergono, memorie che confliggono'. [Online] Available at http:// fermi.univer.it/iperstoria/testi18.htm

Sarfatti, M. (2000) Gli ebrei nell'Italia fascista: Vicende, identità, persecuzione, Einaudi, Turin.

Sarfatti, M. (2001a) 'Ecco perché vogliamo ricordare', La Repubblica, 26 Jan.

Sarfatti, M. (2001b) 'Razzisti per ordine superiore', Mi ricordo, pp. 78-81.

Scialoja, M. (2001) 'Io, post-revisionista', L'espresso, 25 Jan., pp. 89-91.

Segre, C. (2001) 'Olocausto, il ricordo e il monito', Corriere della Sera, 28 Jan.

Shoah Foundation (2006) 'University of Southern California Shoah Foundation Institute'. [Online] Available at: http://www.usc.edu/schools/college/vhi/

Sofri, A. (2001a) 'Le caverne dell'orrore', Mi ricordo, pp. 58-62 (also appeared as 'Lager e Foibe, il derby dell'orrore', La Stampa, 26 Jan.).

Sofri, A. (2001b) 'L'Apocalisse degli ebrei nel cuore dell'Europa', La Repubblica, 28 Jan.

Steinberg, J. (1991) All or Nothing: The Axis and the Holocaust 1941-43, Routledge, London.

Stockholm Declaration (2000) Declaration of the Stockholm International Forum on the Holocaust. [Online] Available at: http://www.holocaustforum.gov.se or http://taskforce.ushmm.org

Teofilo (2001) 'Quante Shoah nel calendario degli ebrei', La Stampa (Turin supplement), 26 Jan.

Ventura, A. (ed.) (1996) L'università dalle leggi razziali alla Resistenza, CLUEP, Padua.

Walston, J. (1997) 'History and memory of the Italian concentration camps', Historical Journal, vol. 40, no. 1 , pp. $169-183$.

Wiedmer, C. (1999) The Claims of Memory: Representations of the Holocaust in Contemporary Germany and France, Cornell University Press, Ithaca.

Wieviorka, A. (1992) Déportation et génocide, Plon, Paris.

Winter, J. (1995) Sites of Memory, Sites of Mourning, Cambridge University Press, Cambridge.

Wyman, D. S. \& Rosenzveig, C. H. (eds) (1997) The World Reacts to the Holocaust, Johns Hopkins University Press, Baltimore.

Young, J. E. (1993) The Texture of Memory: Holocaust Memorials and Meaning, Yale University Press, New Haven.

Zelizer, B. (1998) Remembering to Forget: Holocaust Memory through the Camera's Eye, Chicago University Press, Chicago.

Zuccotti, S. (1987) The Italians and the Holocaust, Peter Halban, London.

Zucotti, S. (2000) Under His Very Windows: The Vatican and the Holocaust in Italy, Yale University Press, New Haven. 